\title{
Pengaruh Kelengkapan Pengisian Medical Discharge Summary Pasien Rawat Inap Terhadap Implementasi SNARS Edisi 1 Elemen Penilaian MIRM 15 di Rumah Sakit AMC Cileunyi
}

\author{
${ }^{1}$ Dina Sonia, ${ }^{2}$ Karin Ayulia Maulinabila \\ Program Studi Rekam Medis dan Informasi Kesehatan, Politeknik Piksi Ganesha Bandung
}

\section{Article Info}

Article history:

Received July 13, 2020

Revised August 18, 2020

Accepted August 29, 2020

\section{Keywords:}

Filings Completeness

Inpatient Medical Discharge

Summary

SNARS

MIRM 15

Medical Record

\begin{abstract}
This research aims to determine the effect of filings completeness of inpatient medical discharge summary on implementation SNARS $1^{\text {st }}$ edition MIRM 15 valuation element at Rumah Sakit AMC Cileunyi. The research method used quantitative method with descriptive approach, The data collecting that by distributing quessioneir, observation, interview and compeleted with literature study which has a close relevance to the problem. The sampling technique used is sampling technique saturated. From the research of this research, the problem that arise among others: 1) The high number of incomplete replenishment of inpatien medical discharge summary. 2) The absence of standard procedure operational (SPO) for discharge summary, and 3) Unfulfilled SNARS accreditation standard 1st edition MIRM 15 valuation element related discharge summary The advice given to fix the problem is 1) Make a review team every room that aims to coordinate and control the incomplete doctor registers. It is expected that the doctor may improve the completeness of the filling of medical records. 2) Socializing the new design in accordance with the provisions of the SNARS edition 1 MIRM 15 valuation element and reinforcing the filing instructions by making the SPO filing discharge summary.
\end{abstract}

This is an open access article under the CC BY-SAlicense.

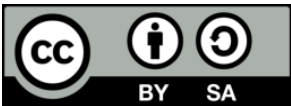

\section{Corresponding Author:}

Dina Sonia, Karin AyuliaMaulinabila

Program Studi Rekam Medis dan Informasi Kesehatan,

Politeknik Piksi Ganesha,

JL. Jendral Gatot Subroto No.301 Bandung

Email: nasoniaonya.ds@gmail.com, auliakarin@gmail.com

\section{PENDAHULUAN}

Rekam medis menurut PerMenKes No.269/MENKES/PER/III/2008 “adalah berkas yang berisikan catatan dan dokumen tentang identitas pasien, pemeriksaan, pengobatan, tindakan dan pelayanan lain yang telah diberikan kepada pasien”. Rekam medis berisikan data klinis dan data administratif yang dilampirkan dalam pemberkasan sesuai dengan pelayanan yang didapat baik itu rawat inap, rawat jalan ataupun gawat darurat, yang harus tersaji secara lengkap dan akurat untuk digunakan sebagai kepentingan administrasi, hukum, finansial, riset, edukasi maupun dokumentasi.

Demi mewujudkan akuntabilitas pelayanan yang baik kepada masyarakat, setiap rumah sakit diwajibkan untuk melakukan akreditasi sesuai dengan Undang-Undang Nomor 
44 Tahun 2009 Pasal 40 ayat 1 yang menyatakan bahwa "Dalam upaya peningkatan mutu pelayanan Rumah Sakit wajib dilakukan akreditasi secara berkala minimal 3 (tiga) tahun sekali". Dalam proses pelaksanaannya akan dilakukan oleh suatu lembaga independen baik dari dalam negeri ataupun luar negeri berdasarkan standar akreditasi yang berlaku. Akreditasi sendiri merupakan pengakuan terhadap mutu pelayanan rumah sakit, setelah dilakukan penilaian bahwa rumah sakit telah memenuhi standar akreditasi.

Standar Nasional Akreditasi Rumah Sakit (SNARS) Edisi 1 ini merupakan ketetapan terbaru yang bersifat nasional dari standar penilaian akreditasi yang di berlakukan oleh pemerintah Indonesia mulai januari 2018, yang terkaji dalam 16 bab. Tujuan utamanya ialah untuk keselamatan pasien dan peningkatan mutu rumah sakit. Rumah sakit yang terakreditasi baik pastinya memiliki mutu pelayanan yang baik pula, salah satunya pada manajemen informasi rekam medis. Rekam medis yang terdokumentasi dengan baik akan disampaikan dan diterima dengan baik oleh penerima informasinya. Dalam pelayanan rawat inap contohnya, rekam medis yang dibuatkan antara lain ringkasan masuk dan keluar, catatan perkembangan, catatan keperawatan dan lainnya sampai dengan pembuatan ringkasan pulang (discharge summary). Ringkasan pulang (discharge summary) ini merupakan lembar atau formulir rekam medis yang meringkas seluruh aspek penting yang didapatkan selama satu periode pelayanan yang berguna untuk kelangsungan perawatan dikemudian hari ataupun nantinya berguna sebagai informasi untuk menunjang kegiatan medis atau aspek lainnya. Dalam standar penilaian MIRM 15 dinyatakan bahwa semua pasien rawat inap harus dibuatkan ringkasan pulang (discharge summary) yang dibuat oleh praktisi yang bertanggung jawab memberikan tindak lanjut asuhan.

Kelengkapan merupakan salah satu kegiatan rekam medis yang tujuan utamanya adalah melakukan identifikasi kelengkapan rekam medis sesuai dengan standar yang telah ditetapkan agar rekam medis menjadi akurat dan lengkap. Setelah penulis melakukan Praktek Kerja Lapangan di Rumah Sakit AMC Cileunyi masih ditemukan beberapa permasalahan yang ada dalam analisis kelengkapan rekam medis rawat inap khususnya, masih di temukan ketidaklengkapan pengisian lembar discharge summary yang dilakukan oleh praktisi medis. Padahal dalam kenyataannya lembar ringkasan pulang yang seharus dibuatkan oleh dokter penanggung jawab sebelum pasien pulang atau keluar rumah sakit. Lembar ringkasan pulang sangat dibutuhkan di era JKN sekarang, dikarenakan lembar ringkasan pulang akan dijadikan alat atau wadah yang nantinya berguna dalam proses pengklaiman atau reimbursment kepada pihak ketiga atau asuransi, dengan tidak lengkapnya pengisian discharge summary akan menghambat kelancaran proses pengklaiman dan reimbursment oleh pihak rumah sakit maupun pihak ketiga. Selain itu ketidaklengkapan lembar ringkasan pulang akan mempengaruhi penilaian dalam proses akreditasi rumah sakit.

\section{METODE PENELITIAN}

A. Jenis Penelitian

Metodelogi penelitian yang digunakan penulis adalah metode kuantitatif dengan pendekatan deskriptif. Penelitian ini dilakukan di Rumah Sakit Annisa Medical Center (AMC), penulis mengambil sampel sebanyak 20 orang petugas rekam medis dan dalam menganalisis KLPCM, penulis menentukan jumlah rekapitulasi kunjungan pasien periode (Januari-Maret) 2018 sebanyak 3.945 dan sampel analisis KLPCM sebesar 98 pasien.

B. Teknik Pengumpulan Data

Teknik pengumpulan data yang digunakan adalah kuesioner dengan memberikan pernyataan tertulis kepada responden, studi pustaka dengan menentukan beberapa literatur yang memiliki relevansi kuat, wawancara dan observasi secara langsung ke lapangan. 
C. Definisi Operasional

Tabel 1. Definisi Operasional Variabel

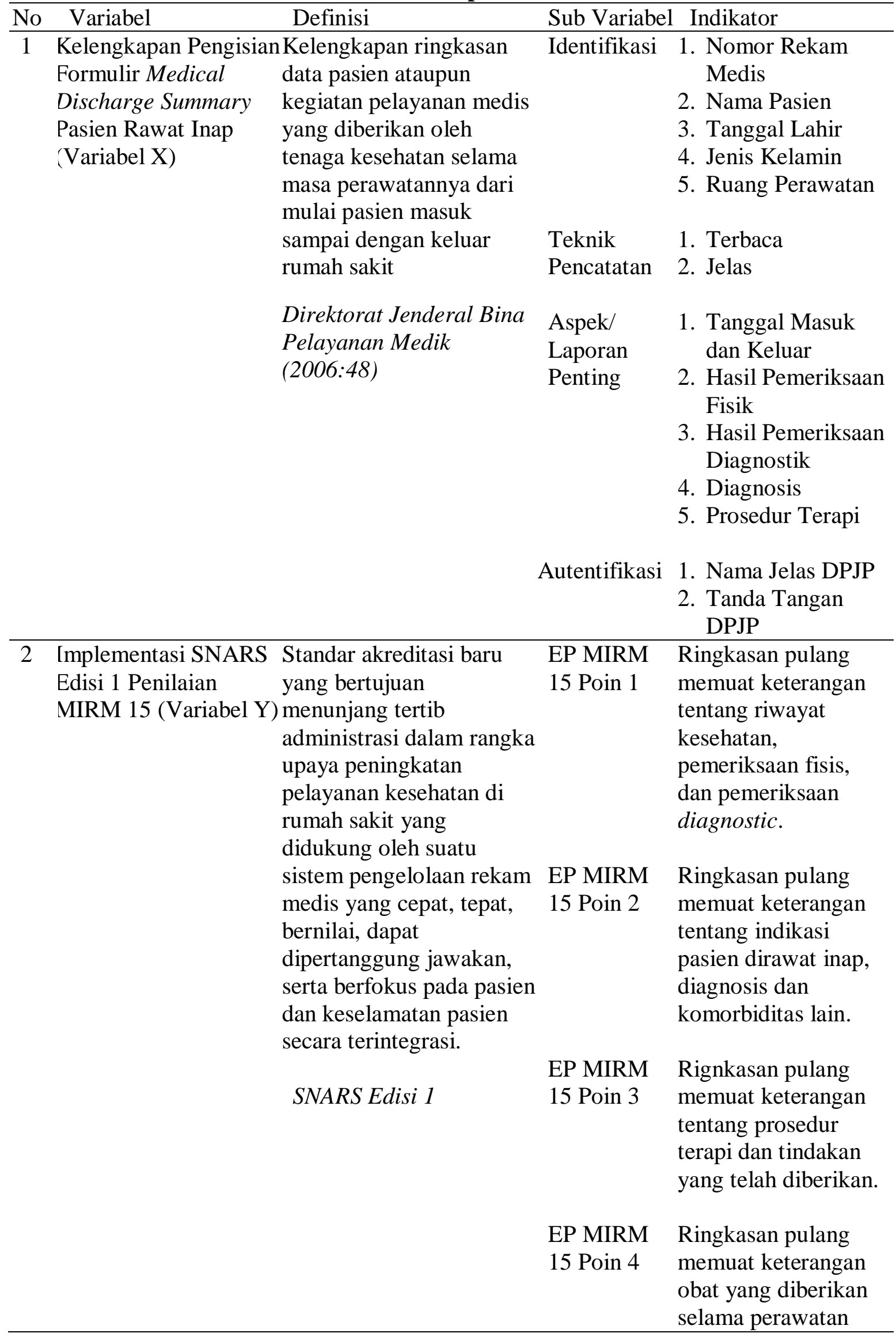


maupun setelah

pasien pulang.

EP MIRM Ringkasan pulang

15 Poin 5 memuat keterangan

tentang kondisi

kesehatan pasien

(status present) saat

akan pulang rumah

sakit.

EP MIRM Ringkasan pulang

15 Poin 6 memuat keterangan

tentang intruksi

tindak lanjut yang

disertai tanda tangan

pasien dan keluarga.

D. Teknik Analisis Data

Teknik analisis data yang digunakan oleh penulis adalah sebagai berikut: 1) Mengelompokkan data berdasarkan variabel dan jenis responden; 2) Mentabulasi data berdasarkan variabel dari seluruh responden; 3) Menyajikan data tiap varabel yang diteliti; 4) Melakukan perhitungan untuk menjawab rumusan masalah; 5) Melakukan perhitungan untuk mengetahui hipotesis yang telah diajukan.

\section{HASIL DAN PEMBAHASAN}

\subsection{Hasil}

\section{Proses Pelaksanaan Kelengkapan di Rumah Sakit AMC}

Kegiatan pengisian catatan medis pasien rawat inap khususnya pada formulir ringkasan pulang sudah sesuai dengan mekanisme dan juknis yang di tetapkan piak rumah sakit akan tetapi masih belum optimal, dikarenakan masih banyaknya temuan rekam medis yang belum terisi dengan lengkap.

Proses pelaksanaan kelengkapan pengisian discharge summary (RM 07) di rumah sakit AMC Cileunyi dilakukan setelah berkas rekam medis dari ruangan disusun dan dirapikan oleh bagian assembling dan di identifikasi oleh bagian coding pengolahan data mengenai diagnosa dan tindakan yang diberikan, kemudian hasil identifikasi ditulis ke dalam post-it dan dilampirkan di atas ringkasan pulang yang masih belum lengkap khususnya untuk pasien rawat inap yang menggunakan BPJS.

\section{Hasil Analisis Ketidaklengkapan}

Kelengkapan pengisian catatan medis khususnya pada lembar discarge summary pasien rawat inap di rumah sakit AMC masih terbilang rendah, hal tersebut dapat dilihat dari rendahnya persentase kelengkapan dan tingginya angka ketidaklengkapan pengisian medical discharge summary yang teridentifikasi dalam analisis KLPCM dengan jumlah rekapitulasi kunjungan pasien periode (Januari-Maret) 2018 diperoleh hasil sebagai berikut:

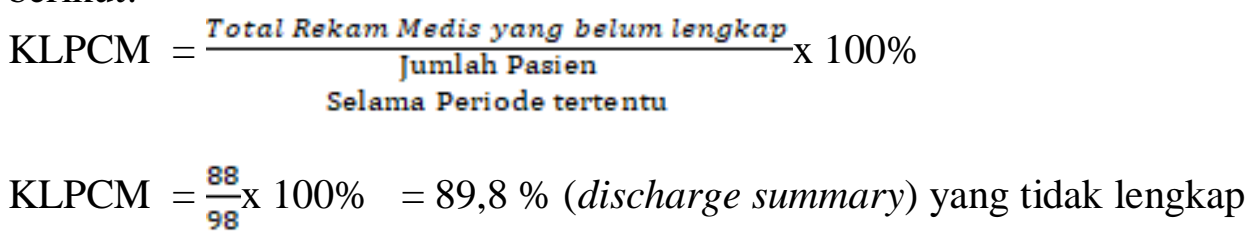




\section{Hasil Pengujian Analisis Data}

1. Uji Validitas

Uji validitas digunakan untuk mengetahui valid atau tidak validnya butir petanyaan atau penyataan dalam kuesioner, butir pernyataan dalam kuesioner/angket dikatakan valid apabila nilai $r$ hitung $\geq$ nilai $r$ tabel, Dalam penelitian ini penulis melakukan uji validitas kontruksi (Construct Validity) dengan menggunakan rumus korelasi pearson product moment dengan hasil uji validitas berdasarkan hasil pengolahan menggunakan SPSS versi 20 sebagai berikut:

$r_{\mathrm{xy}}=\frac{n \sum x y-\left(\sum x\right)(\Sigma y)}{\sqrt{\left(n \sum x^{2}-\left(\sum x\right)^{2}\right\}\left\{n \sum y^{2}-\left(\sum y\right)^{2}\right\}}}$

Tabel 2. Uji Validitas

\begin{tabular}{ccc}
\hline Nilai $\mathrm{r}_{\text {hitung }}$ & Nilai $\mathrm{r}_{\text {tabel }}$ & Hasil Uji Validitas \\
\hline 0,465 & 0,444 & Valid \\
\hline 0,656 & 0,444 & Valid \\
\hline 0,815 & 0,444 & Valid \\
\hline 0,660 & 0,444 & Valid \\
\hline 0,602 & 0,444 & Valid \\
\hline 0,590 & 0,444 & Valid \\
\hline 0,541 & 0,444 & Valid \\
\hline 0,788 & 0,444 & Valid \\
\hline 0,731 & 0,444 & Valid \\
\hline 0,712 & 0,444 & Valid \\
\hline 0,612 & 0,444 & Valid \\
\hline 0,577 & 0,444 & Valid \\
\hline
\end{tabular}

Kesimpulan: Hasil di atas menunjukkan bahwa $r$ hitung $\geq$ nilai $r$ tabel, maka butir pernyataan dalam kuisioner dinyatakan valid.

2. Uji Reliabilitas

Uji reliabilitas digunakan untuk mengetahui konsisten (reliable) atau tidak konsistennya jawaban untuk setiap butir petanyaan atau penyataan dalam kuesioner, butir pernyataan dalam kuesioner/angket dikatakan reliabel apabila nilai koefisien reliabilitas atau cronbach alpha $\geq 0,60$ (Sekaran,1992). Berikut ini rumus alpha cronbach dan hasil uji reliabilitas berdasarkan hasil pengolahan menggunakan SPSS versi 20:

$R=\alpha=\frac{N}{N-1}\left(\frac{S^{2}\left(1-\sum S_{i}\right)^{2}}{S^{2}}\right)$

Tabel 3. Uji Reliabilitas

\begin{tabular}{l|l}
\hline \multicolumn{2}{l}{ Reliability Statistics } \\
\hline Cronbach's Alpha & N of Items \\
\hline .906 & 12 \\
\hline
\end{tabular}

Kesimpulan: Hasil di atas menunjukkan bahwa nilai koefisien reliabilitas atau cronbach alpha $\geq 0,60$ dengan jumlah $\mathrm{N}$ of Item atau butir pernyataan kuisioner sebanyak 12 dan nilai cronbach alpha sebesar 0,906, maka butir pernyataan kuisioner dinyatakan reliabel atau konsisten. 
3. Uji Regresi Linear Sederhana

Uji regresi linear sederhana digunakan untuk menganalisis apakah terdapat hubungan timbal balik atau sebab-akibat antar variabel independent $(\mathrm{X})$ terhadap variabel dependent (Y). Berikut ialah rumus persamaan dan hasil uji regresi linear sederhana:

$$
Y^{\prime}=a+b X
$$

Tabel 4. Uji Regresi Linear Sederhana

\begin{tabular}{llllll}
\hline \multicolumn{7}{c}{ Coefficients $^{\mathrm{a}}$} & & & \\
\hline \multirow{2}{*}{ Model } & \multicolumn{2}{l}{$\begin{array}{l}\text { Unstandardized } \\
\text { Coefficients }\end{array}$} & $\begin{array}{l}\text { Standardized } \\
\text { Coefficients }\end{array}$ & & Sig. \\
\cline { 2 - 5 } & $\mathrm{B}$ & Std. Error & Beta & & \\
\hline \multirow{2}{*}{1 (Constant) } & 8.283 & 3.094 & & 2.677 & .015 \\
\cline { 2 - 6 } Kelengkapan ringkasan pulang & .626 & .134 & .740 & 4.671 & .000 \\
\hline
\end{tabular}

a. Dependent Variable: SNARS edisi 1 Penilaian MIRM 15

Kesimpulan: Hasil uji regresi linear sederhana di atas menunjukkan nilai konstan (a) sebesar 8,283 dan nilai kelengkapan ringkasan pulang (b) sebesar 0,626 sehingga rumus persamaan regresi dari hasil tersebut adalah $\mathrm{Y}=8,283+0,626 \mathrm{X}$, yang berarti bahwa dalam setiap penambahan $1 \%$ nilai kelengkapan medical discharge summary maka nilai implementasi SNARS Edisi 1 elemen penilaian MIRM 15 bertambah sebesar 0,626, nilai koefisien regresi bernilai positif sehingga dapat dikatakan bahwa arah pengaruh antara variabel $\mathrm{X}$ dan variabel $\mathrm{Y}$ adalah positif.

4. Uji Hipotesis Terhadap Korelasi (Uji T Hipotesis)

Uji t hipotesis digunakan untuk menguji kebenaran suatu pernyataan (hipotesis) dan menarik kesimpulan apakah pernyataan tersebut dapat diterima atau pernyataan tersebut di tolak. Dalam penelitian ini penulis memiliki pernyataan (hipotesis) sebagai berikut:

$\mathrm{H}_{0}$ : Kelengkapan pengisian medical discharge summary pasien rawat inap tidak berpengaruh terhadap implementasi SNARS Edisi 1 elemen penilaian MIRM 15 di Rumah Sakit AMC Cileunyi.

$\mathrm{H}_{1}$ : Kelengkapan pengisian medical discharge summary pasien rawat inap berpengaruh terhadap implementasi SNARS Edisi 1 elemen penilaian MIRM 15 di Rumah Sakit AMC Cileunyi.

Berikut penulis paparkan nilai $t_{\text {tabel }}$ dan hasil uji $t$ hipotesis yang penulis olah menggunakan SPSS versi 20:

Tabel 5. Uji Hipotesis Terhadap Korelasi (Uji T Hipotesis)

\begin{tabular}{ll}
\hline Nilai $t_{\text {hitung }}$ & Nilai $t_{\text {tabel }}$ \\
\hline 4,671 & 2,101 \\
\hline
\end{tabular}

Kesimpulan: Hasil uji t hipotesis di atas menunjukkan nilai $\mathrm{t}_{\text {hitung }}$ sebesar 4,671 dengan nilai $t_{\text {tabel }}$ sebesar 2,101. Hipotesis penelitian $\left(\mathrm{H}_{1}\right)$ dapat diterima dan Hipotesis alternatif $\left(\mathrm{H}_{0}\right)$ ditolak apabila nilai $\mathrm{t}_{\text {hitung }} \geq \mathrm{t}_{\text {tabel }}$. Berdasarkan hasil pengujian di atas dapat disimpulkan bahwa pernyataan hipotesis penelitian $\left(\mathrm{H}_{1}\right)$ bahwa kelengkapan pengisian medical discharge summary pasien rawat inap berpengaruh terhadap implementasi SNARS Edisi 1 elemen penilaian MIRM 15 di Rumah Sakit AMC Cileunyi dapat diterima, karena nilai thitung sebesar $4,671 \geq$ nilai tabel sebesar 2,101 .

5. Uji Koefisien Determinasi $\left(\mathrm{R}^{2}\right)$

Uji koefisien determinasi digunakan untuk mengukur derajat hubungan antar dua buah variabel atau lebih. Berikut ini tabel interval koefisien korelasi dan hasil uji koefisien determinasi $\left(\mathrm{R}^{2}\right)$ : 
Tabel 6. Uji Koefisien Determinasi $\left(\mathbf{R}^{2}\right)$

\begin{tabular}{ccccc}
\hline \multicolumn{5}{c}{ Model Summary } \\
\hline Model & $\mathrm{R}$ & $\mathrm{R}$ Square & Adjusted R Square & Std. Error of the Estimate \\
\hline 1 & $.740^{\mathrm{a}}$ & .548 & .523 & 2.190 \\
\hline
\end{tabular}

a. Predictors: (Constant), Kelengkapan ringkasan pulang

Kesimpulan: Hasil uji koefisien determinasi $\left(\mathrm{R}^{2}\right)$ di atas menunjukkan nilai $\mathrm{R}^{2}$ pada kolom R Square sebesar 0,548 yang berarti bahwa pengaruh kelengkapan pengisian medical discarge summary pasien rawat inap terhadap implementasi SNARS Edisi 1 elemen penilaian mirm 15 di Rumah Sakit AMC sebesar 54,8\% sedangkan sisanya sebesar 45,2\% dipengaruhi oleh variabel lain atau error. Berdasarkan hasil diatas juga dapat disimpulkan bahwa terdapat hubungan yang kuat antara variabel $\mathrm{X}$ dan variabel $\mathrm{Y}$ dilihat dari interval nilai koefisien korelasi pada interval koefisien korelasi, dengan nilai koefisien korelasi pada kolom $\mathrm{R}$ dalam tabel model summary sebesar 0,740 yang menunjukkan tingkat hubungan yang kuat.

\subsection{Pembahasan}

Permasalahan yang Timbul Mengenai Pengaruh Kelengkapan Pengisian Medical Discharge Summary Terhadap Implementasi SNARS Edisi 1 Elemen Penilaian MIRM 15 di Rumah Sakit AMC Cileunyi

Berdasarkan hasil penelitian yang penulis lakukan di Rumah Sakit AMC Cileunyi, penulis menemukan beberapa permasalahan yang timbul mengenai kelengkapan pengisian medical discharge summary pasien rawat inap terhadap implementasi SNARS Edisi 1 elemen penilaian MIRM 15 di rumah sakit AMC, adapun permasalahan tersebut yaitu sebagai berikut:

1. Tingginya angka ketidaklengkapan catatan medis khususnya dalam pencatatan ringkasan pulang (discharge summary) pasien rawat inap, dikarenakan masih ditemukannya ringkasan pulang (discharge summary) pasien rawat inap yang belum dilengkapi setelah pasien pulang atau keluar dari rumah sakit, hal tersebut belum sesuai dengan juknis yang ditetapkan oleh pihak rumah sakit yang dalam ketentuannya DPJP mengisi dan melengkapi ringkasan pulang ketika pasien pertama kali memasuki ruang rawat inap.

2. Belum terpenuhinya nilai standar dalam SNARS Edisi 1 elemen penilaian MIRM 15 berkaitan ringkasan pasien pulang (discharge summary).

\section{Upaya Pemecahan Permasalahan Mengenai Pengaruh Kelengkapan Pengisian Medical Discharge Summary Pasien rawat Inap Terhadap Implementasi SNARS Edisi 1 Elemen Penilaian MIRM 15 di Rumah Sakit AMC}

Berdasarkan hasil wawancara yang penulis lakukan bersama kepala instalasi rekam medis rumah sakit AMC. Adapun upaya yang telah dilakukan oleh pihak rumah sakit adalah sebagai berikut:

1. Mensosialisasikan Standar Operasional Prosedur (SOP) ke bagian dokter yang tidak melengkapi lembar ringkasan pulang, mengkoordinasikan dengan komite medik dan bagian manajemen untuk mendata dan memaparkan dokter mana saja yang tidak mengisi ataupun melengkapi lembar ringkasan pulang pendataan ini dilakukan untuk pemberian punishment kepada dokter yang lalai. Hal ini dilakukan agar meningkatnya angka kelengkapan dalam pengisian ringkasan pulang (discharge summary).

Untuk memenuhi implementasi standar SNARS Edisi 1 pihak instalasi rekam medis bekerja sama dengan bagian PMKP untuk mutu rekam medis, melakukan presentasi berupa pemaparan grafik hasil kerja kepada direktur dan wakil direktur, serta membuat design baru sesuai dengan ketentuan dalam SNARS Edisi 1. 


\section{KESIMPULAN}

Berdasarkan hasil penelitian yang dilakukan penulis di Rumah Sakit AMC Cileunyi pada 28 Maret s.d 28 Mei 2018, diperoleh informasi mengenai pelaksanaan kelengkapan pengisian medical discharge summary (ringkasan pulang) pasien rawat inap di Rumah Sakit AMC sudah sesuai dengan mekanisme dan juknis yang ditetapkan oleh rumah sakit hanya saja belum optimal dikarenakan masih banyak ditemukan berkas rekam medis khususnya formulir ringkasan pulang (discharge summary) yang belum dilengkapi saat berkas turun dari ruang rawat inap ke bagian instalasi rekam medis.

Berdasarkan hasil pengujian penelitian yang dilakukan dengan menggunakan SPSS versi 20 dengan tingkat kepercayaan sebesar $95 \%$ pada 20 jumlah responden sebagai sampel teliti, diperoleh nilai thitung sebesar 4,671 dengan nilai $t_{\text {tabel }}$ sebesar 2,101 yang menyatakan adanya pengaruh kelengkapan pengisian ringkasan pulang pasien rawat inap terhadap implementasi SNARS Edisi 1 (penilaian MIRM 15) di rumah sakit AMC dengan besaran pengaruh sebesar 54,8\% dan sisanya sebesar 45,2\% dipengaruhi oleh variabel lain atau error, dengan persentase angka ketidaklengkapan pencatatan medis di rumah sakit AMC sebesar $89,8 \%$.

Permasalahan yang timbul pada pengaruh kelengkapan pengisian ringkasan pulang pasien rawt inap terhadap implementasi SNARS Edisi 1 (penilaian MIRM 15) di rumah sakit AMC, yaitu tingginya angka ketidaklengkapan catatan medis khususnya dalam pencatatan ringkasan pulang pasien rawat inap, dikarenakan masih ditemukannya ringkasan pulang pasien rawat inap yang belum dilengkapi setelah pasien pulang atau keluar dari rumah sakit, hal tersebut belum sesuai dengan juknis yang ditetapkan oleh pihak rumah sakit, dan belum adanya standar operasional prosedur (SOP) untuk pengisian resume medis serta belum terpenuhinya nilai standar dalam SNARS Edisi 1 elemen penilaian MIRM 15 berkaitan ringkasan pasien pulang.

Upaya pemecahan permasalahan mengenai pengaruh kelengkapan pengisian ringkasan pulang pasien rawt inap terhadap implementasi SNARS Edisi 1 (penilaian MIRM 15) di rumah sakit AMC, antara lain: mensosialisasikan SOP kepada dokter terkait, berkoordinasi dengan komite medic dan pihak manajemen untuk mendata dan memaparkan dokter-dokter yang tidak melengkapi ringkasan pulang untuk pemberian punishment, melakukan kerjasama dengan bagian PMKP untuk mutu rekam medis, melakukan presentasi grafik kepada direktur dan wakil direktur, serta membuat design baru sesuai dengan ketentuan SNARS Edisi 1 terkait ringkasan pulang.

\section{REFERENCES}

Budi, Savitri Citra. (2011). Manajemen Unit Kerja Rekam Medis. Quantum Sinergi Medis: Bantul.

Direktorat Jenderal Pelayanan Medik. (2006). Pedoman Penyelenggaraan dan Prosedur Rekam Medis di Indonesia. Direktorat Jenderal Bina Pelayanan Medik: Jakarta.

Haryanto, Slamet. (2017). Pengaruh Kelengkapan Formulir Catatan Perkembangan Pasien Terintegrasi Rawat Inap Teradap Mutu Rekam Medis di Rumah Sakit Al-Islam Bandung. Politeknik Piksi Ganesha Bandung: Bandung.

Hatta, Gemala R. (2013). Pedoman Manajemen Informasi Kesehatan di Sarana Pelayanan Kesehatan. Universitas Indonesia (UI-Press): Jakarta.

Huffman, Edna K. (2006). Health Information Management, Physician Record Compay: Berwyn, Illinois. 
Notoadmojo, Soekidjo. (2010). Metode Penelitian Kesehatan. Rineka Cipta: Jakarta.

Permenkes RI No. 269/MENKES/PER/III/2008 Tentang Rekam Medis. Jakarta: Kemenkes RI.

Permenkes RI No. 340/MENKES/PER/III/2010 Tentang Klasifikasi Rumah Sakit. Jakarta: Kemenkes RI.

Priyatno, Dewi. (2012). Cara Kilat Belajar Analisis Data dengan SPSS 20. ANDI: Yogyakarta.

S. Rano Indradi. (2017). Rekam Medis. Universitas Terbuka: Banten.

Sugiyono. (2013). Metode Penelitian Kuantitatif, Kualitatif dan $R \&$ D. Alfabeta: Bandung.

Sugiyono. (2015). Metode Penelitian Kuantitatif, Kualitatif dan $R$ \& D. Alfabeta: Bandung.

Sutoto, dkk (2018). Standar Nasional Akreditasi Rumah Sakit Edisi 1 Tahun 2018. KARS: Jakarta.

Undang-Undang No. 34 Tahun 2017 Tentang Akreditasi Rumah Sakit. Jakarta: Kemenkes RI.

Undang-Undang No. 36 Tahun 2009 Tentang Kesehatan. Jakarta: Kemenkes RI.

Undang-Undang No. 44 Tahun 2009 Tentang Rumah Sakit. Jakarta: Kemenkes RI.

\section{BIOGRAPHIES OF AUTHORS}

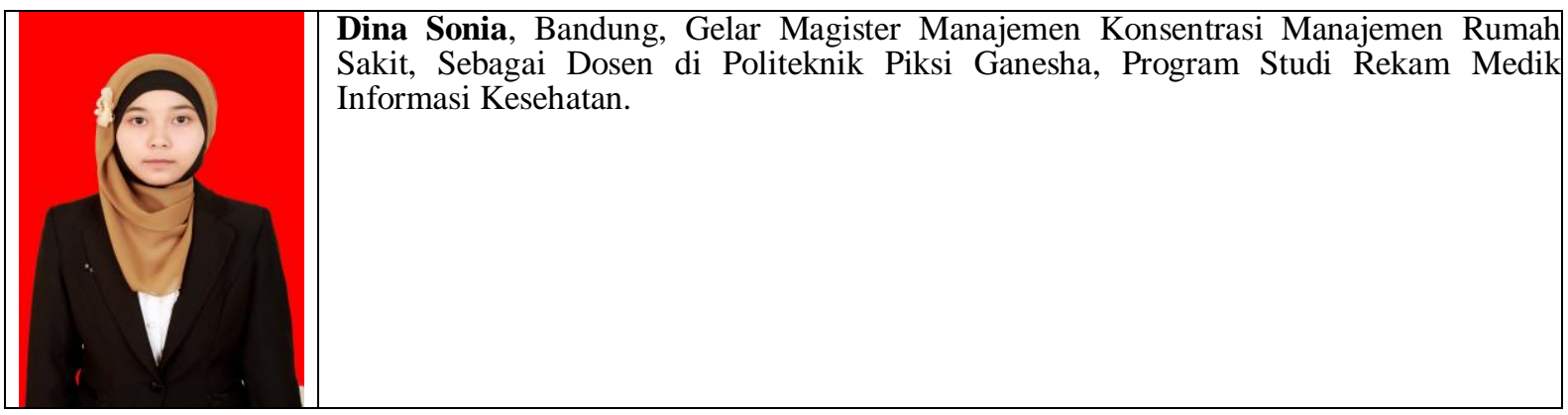

